\title{
INNOVATION AND CREATIVITY AS A PREREQUISITE TO SUSTAINABLE COMPETITIVE ADVANTAGES
}

\author{
Mirjana Nedović ${ }^{1}$ \\ Sandra Mrvica Mađarac ${ }^{2}$ \\ Ivona Bajić Sabljo ${ }^{3}$
}

DOI: https://doi.org/10.31410/LIMEN.2019.157

\begin{abstract}
Innovation and creativity represents the key assumption when creating competitive advantage for any of the market participant. It is quite sure that without creativity and innovative products and services that already exist or are about to appear at the market, it's not possible to achieve a long-term competitive advantage. The turbulent market and the increasingly demanding consumers who have become picky in the mass of products and services that do meet the same need, presently the added value and unique characteristics of the products and services have become crucial when choosing a product. The purpose of the paper is to highlight the importance of introducing competitive characteristics to products and services as well as introducing innovations to Croatian companies. The aim of this paper is to indicate that there is a room for improvement when it comes to competitiveness and innovation in the Republic of Croatia, as well as for the future predictions within this area. The research methodology is based on the application of analysis and synthesis methods, and methods of comparison and descriptive methods.
\end{abstract}

Keywords: Competitiveness, Innovation, Competitive advantage, Uniqueness of products and services.

\section{WHAT ARE INNOVATIONS?}

$\mathrm{W}$ hen it comes to innovation then it can be said that they are preceded by creativity. Innovation has a large impact on achieving the positive economic goals of all market players. It is hard to imagine that any market economy operator on the market can be competitive without the innovation processes, products or services that are subsequently offered to the consumers on the market. In the literature there are numerous definitions of innovation. Innovations can be viewed from numerous perspectives.

We can observe them in the context of the application of the new technologies, so it can be products and services that are obtained on the basis of the research results. When it comes to technology, it can be said that it is the knowledge of how to do something (Sikavica \& Novak, 1999).

Human capital and its knowledge have a great influence on finding the new innovative solutions. Investments in human capital development are a necessity for the purpose of creating new products and services as well as processes. Rightly so, the development of the new products, services and processes are of critical importance for growth development and survival of the company. Innovations are the most important factor that pushes the company's goals forward, allowing the company to continuously create added value to satisfy the needs of consumers and also to satisfied the existential needs of the company (Prester, 2006).

\footnotetext{
$\overline{1}$ College of Applied Sciences „Lavoslav Ružička” in Vukovar, Županijska 50, 32000 Vukovar, Croatia

2 College of Applied Sciences „Lavoslav Ružička” in Vukovar, Županijska 50, 32000 Vukovar, Croatia

3 Regional Wholesale Market Osijek Inc., Ul. Svetog Leopolda Bogdana Mandića, 31000 Osijek, Croatia
} 
It is quite clear that in modern business conditions, innovation in any field influences on the further fate of an enterprise in terms of its survival and competitiveness or its disappearing from the market. To recognize customer preferences and to meet their needs better and faster than the competition certainly provides a competitive advantage.

To be innovative, by developing new or by improving the existing products, processes and / or business, can help the company to recognize and meet the desires and needs of customers, and on this way to achieve a competitive advantage (Miloloža, 2016).

At the company level, the innovation is most often manifested through the adoption of new ideas or the improvement of an existing product, service, device, system, policy or program (Damanpour \& Gopalakrishnan, 2001).

Today, market entities are operating in the turbulent market conditions, and as they are oriented towards the market, they can be targeted by competitor's imitators. Each market subject for them to understand how good or bad it is, it compares itself with its competitors, and consequently intensely monitors all the steps of a competitor's appearance on the market. By comparing the company with its first competitor, company has been made aware of its qualities and advantages, but also those of its competitors.

Comparing and monitoring competition is not an obstacle to incite innovative product or service solutions, but even the opposite: it can be an extremely good incentive to find better innovative products and services by adding unique features that are hard-to-imitate. What is found to be more difficult to imitate competition in any of its segments, in fact we ensure our competitive advantage over the long period of time.

Market entities should clearly understand what kind of innovation they want, and also what are the results of the innovation they do expect. It is therefore recommended that each economic subject develops a set of questions to ask themselves about the goals that innovation seeks to achieve:

1. How much will innovation cost?

2. For how commercially visible will it really be?

3. How much will it contribute to the value: i.e. how much will it be worth if realized?

4. What will be learned in case the innovation fails to implement? (Dess, Lumpkin, \& Eisner, 2010).

Before we get on to the process of innovation, it is completely compulsory to examine all the possibilities and look at the situation in which the market subject will find itself even in the case innovation do not live up to the market.

Crawford (1994) lists five dimensions (see figure 1), by which it defines a new product.

Building a success is possible on all dimensions, however, the range in which something is defined as a new product goes from products for which they were made minimum readjustments, to the product that is completely new when we've come across it and also familiarized with all its characteristics (Grbac, Dlačić, \& First, 2007). 
It must be noted that the market as well as the consumers, i.e. the buyers must be ready for a new and innovative product, because otherwise if the company launches an innovation on unprepared market with unprepared customers to accept such innovation, we may finish with the negative results instead of the expected positive ones.

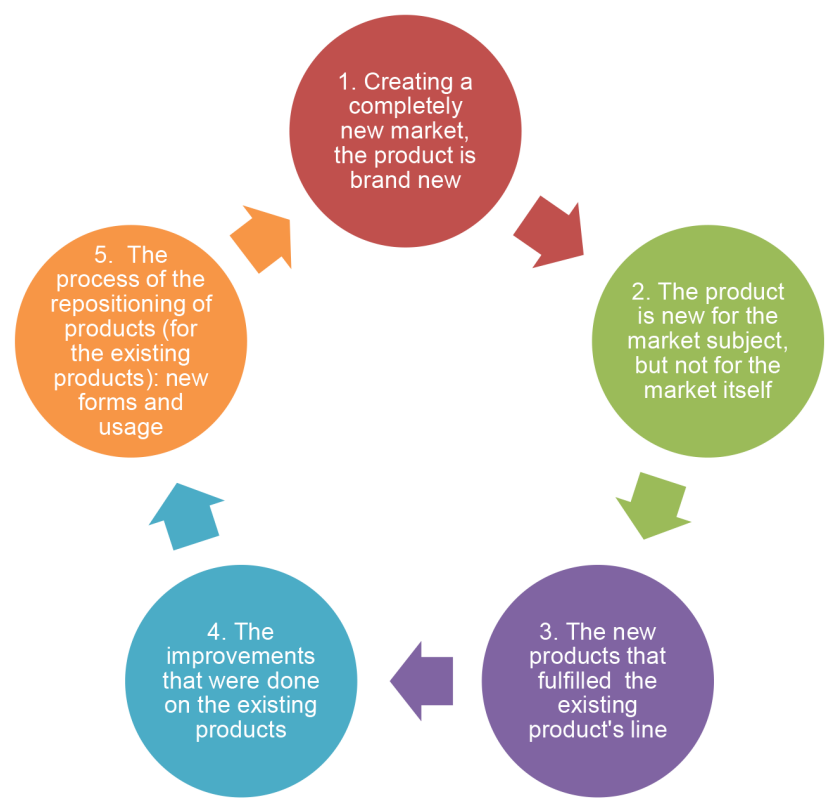

Figure 1. The five dimensions that define a new product

Source: Crawford (1994), New Products Management, adapted.

„Not every company that succeeds at shipping its innovative product to market manages to derive benefits from this innovation. If a new product offers features that customers do not either understand or appreciate, it will not manage to attract customer attention. This happens when a company inaccurately predicts consumer preferences and market demand developing a product that customers either do not want at all or are not ready for yet" (Khessinaa, Goncaloa, \& Krause, 2018).

\subsection{Innovations in the Republic of Croatia}

According to data released from the Croatian Central Bureau of Statistics (2018), in relation to what has been reported in this First Release was the outcome of the survey on innovation activities and enterprises that was conducted from 2014 to 2016 on a sample of 4500 enterprises. According to this survey, innovative enterprises are defined as enterprises that introduced either a product or process innovation, or organizational or marketing innovation that was given in the course of the reporting period. Between 2014 and 2016, there were 43,4\% of innovative enterprises in the Republic of Croatia.

The share of innovative enterprises grows with the enterprise size. There were $40,5 \%$ small, $53,0 \%$ medium - sized and 71,7\% large enterprises that were innovative. Industrial enterprises had the largest share in innovation activities $(47,7 \%)$, while $40,8 \%$ of service enterprises were innovative.

Market subjects invest energy in creating innovative activities, but there is still a room for further improvements. 
According to the Strategy for innovation encouragement of the Republic of Croatia 2014-2020, is clearly indicated the importance of applying innovations in the economy and in all fields of work. It was adopted in December of 2014, and it seeks to focus on the long-term development and systematic stimulation of innovation as a fundamental value for the success of the economy, but also of society as a whole.

When we considered the situation in the Republic of Croatia, there is also a tendency to improve the innovation system and also the legislative and fiscal framework, to determine the method of communication and models of cooperation between the public, scientific and research sector and the business sector in order to develop new products, services, business processes and technology, as well as the way of application results of scientific research work in economy and society as a whole (Ministry of Economy, Entrepreneurship and Crafts, 2018).

The innovation processes in the Republic of Croatia needs to be better communicated with the public and the real sector needs to be better and more closely linked to scientific institutions for better synergy. Innovation is the driver of development of any economy. It is a prerequisite for creating a competitive advantage, so it needs to be very carefully studied and prioritized.

\section{THE CREATIVITY AS A BASIS FOR INNOVATIONS}

Creativity represents a driving force and an endeavour to offer something new and different to the market or to the consumers. Creativity observed as a skill or capability is highly desirable and today is encouraged in almost all areas of business. There are numerous definitions found in the literature that describes creativity.

Creativeness is the ability to create unique and new solutions, ideas, products and the like. The results must be original and statistically rare to find. A creative work in particular culture must be judged as valuable, useful, and usable (in the field of the activity in which it has originated), i.e. what is new or different is not always creative but is often unaccepted or weird. Creativity includes: creative products, creative individuals (or groups), creative processes and the creative environment.

The course of creative thinking is a process that has a creative outcome and has several stages: preparation - familiarizing with the problems or issues and preparing to solve them; incubation - in contemporary cognitive psychology it's a part of the process in which parallel mental associations do occur; insight - sudden, rapid solution; evaluation and elaboration - translating the solution into an environmentally friendly product. It is not necessary for the creative process to have all these changes. In psychology, creative thinking is equated with divergent thinking, which is: flexible, fluent and original. Inventive and creative thinking is the process of connecting concepts and things in a new and unfamiliar way, by noting connections between phenomena and things that are not always obvious. Intellectual development (or the so-called convergent thinking) and creativity are not interrelated, but a certain level of intelligence is necessary precondition for creativity. It has not been proven that a special personality structure exists in persons who are called „creative personalities”. Today, modern psychology holds that for the most people are creative (Miroslav Krleža Institute of Lexicography).

Creativity is most often viewed through two conceptual frameworks: 1) as a creative potential, that is, an individual's ability to create something new and useful, which is most often measured by divergent thinking tests, and 2) as a creative achievement - the realization of those ideas as 
useful achievements, which are most commonly measures through self-assessments of accomplishments across different fields of human activities (Jauk, Benedikt, Dunst, \& Neubauer, 2013).

The creating of new ideas and solutions is a necessity for survival on the market. Without creativity that is associated with innovation, new products and services cannot be realised. There is a need to reflect in this direction and to stimulate creativity in order to reach full expression in all business areas. It is necessary to be aware that in every individual lay a potential for creativity that needs to be developed and encouraged, that is, to use creative processes when solving business problems.

\section{ENCOURAGING THE CREATIVITY AND INNOVATIONS - THE COMPETITIVE ADVANTAGE}

The creation of a sustainable competitive advantage is the desire of every market entity, and to maintaining it over time poses a real challenge in business. Being competitive implies that the market entity is successful on the market and that it achieves the previously set goals. No matters in which industry they compete some of the businesses are more successful, more profitable and more visible than the others.

Competitive advantage brings value to the customer in a better way than competitors. For the value that gets the customer is willing to pay. If the value is higher than expected (than that was expected by the buyer), the market entity has an advantage over other competitors.

According to Porter (1985), the competitive advantage starts from the assumption that it can come from many different sources, and it shows how such advantage can be related to certain activities, but also to the way in which these activities are related to each other, and to supplier and customer activities. Porter distinguishes two types of competitive advantage: low cost and differentiation.

An innermost issue in a competitive strategy is the relative position of companies within the industry. By positioning we determine whether a company's profitability is above or below the industry average. The company that is well positioned can earn higher rates of return, even if the industrial structure is unfavourable and the average industry profitability is modest (Vrdoljak Raguz \& Tolušić, 2012).

How competitive advantage can have a foothold from several sources, one of the sources of competitive advantage is offering innovative and creative solutions for the product or service that will represent value to the consumer. By fostering a creative mindset, it will lead to innovation, and then to the competitive advantage. Therefore, market participants should focus on these two areas in order to, as a logical sequence, derived competitive advantage.

\section{THE COMPETITIVENESS OF THE REPUBLIC OF CROATIA}

World Competitiveness Report 2017-2018 ${ }^{14}$ shows that amongst the TOP 10 most competitive countries in the world are: Switzerland, the United States, Singapore, the Netherlands, Germany, Hong Kong, Sweden, the United Kingdom, Japan and Finland. Estonia is on $29^{\text {th }}$ place,

Competitiveness Assessment and Measurement Methodology - The results of the Report are based on a survey of businesses in 14000 enterprises worldwide, encompassing the statistical data from 2016 and 2017 and data from international organizations: World Bank, OECD, IMF, WHO, UNESCO. In the spring of 2017, 84 heads from the business sector were interviewed in Croatia. This report includes 137 countries. 
Czech Republic on 31, Poland 39, and Lithuania on $41^{\text {st }}$ place. Circle of TOP 50 enclose Slovenia on $48^{\text {th }}$ place and Bulgaria on $49^{\text {th }}$. Romania is at $68^{\text {th }}$ place. Croatia is ranked $74^{\text {th }}$ in the group of Albania (75), Montenegro (77) and Serbia (78).

When considering that Croatia remains 74th in terms of global competitiveness, it can be said that its economy is stagnant. In order for Croatia to be on the path of growing Central and Eastern European transition countries, the medium-term (2020) or at least the long-term goal (2025) should be entering in the TOP 45 countries. The question is only where those countries will be then. Competitiveness is measured not only through domestic improvements, but also through leaps that are relative to others. This is why far greater ambitions and holistic approaches to public policy are needed than more moderate reform moves.

Data for Croatia are provided by the National competitiveness council (NCC), which emphasizes, among the other things, that is necessary: 'Together with the development of the scientific and educational system, to strengthen the technological readiness of the economy to apply new knowledge to the creation of new products and services that will, through deeper specialization and growth of productivity, enable successful entry of companies into new markets. It also should be encouraged export oriented direct foreign investments to enable the production of higher end value-added goods and to have a positive impact on the level of competitiveness." (Economic Lab \& Policy Centre, 2017)

The Republic of Croatia needs to move towards increasing competitiveness in all areas, together with the competitiveness of new products that may emerge as a result of innovations, which will then form basic for creativity and innovations. Therefore, it is imperative that the management of each market subject, regardless of whether it is a product or a service, places particular emphasis on these major factors that can affect greater competitiveness, not only at the company level but also at the national level.

Management of innovation and new products requires special attention, so today we can talk about management of innovation where the main purpose and meaning will be to offer to the market a new product or service that will be characterized by a unique exceptionality, with improved quality and a modified product and services which will stand out from the competition.

\section{CONCLUSION}

Creativity and innovations are prerequisites for creating a competitive edge. They represent an opportunity to move the Republic of Croatia closer to the countries that are at the forefront of competitiveness.

It can be said that through innovation creates opportunities for the market subjects to maintain competitive advantage. In order to achieve a competitive advantage, it is necessary to work more and better on creative ideas and solutions. The role of the state is of great importance in achieving competitiveness, because through certain measures and incentives, it can directly positively influence on the aforementioned, i.e. to stimulate a positive environment and bid financially support innovative solutions of market entities, new products, services, etc.

Lifelong learning also plays an important role in society and should be imposed stronger and better in order to deliver results in the field of innovation. Connecting of scientific institutions 
and the private sector is one way of working together that can bring benefits to society as a whole, but also to the realization of their own interests and goals.

The quality of products and services, apart from innovative solutions, must be the foundation of everything. Without an adequate level of quality, competitiveness cannot be achieved. For products and services except that they should meet the needs of the consumers they should also have unique features that will set them apart from other available products on the market.

It is quite certain that long-term competitiveness has its starting point in both quality and innovative solutions.

\section{REFERENCES}

Crawford, M. (1994). New Products Management. New York: Irwin.

Damanpour, F., \& Gopalakrishnan, S. (2001). pp. 45-46.

Damanpour, F., \& Gopalakrishnan, S. (2001). The dynamics of the adoption of product and process innovations in organisations. Journal of Management Studies, 1, pp. 45-46.

Dess, G., Lumpkin, G., \& Eisner, A. (2010). Strategic Management. New York: McGraw-Hill Irwin.

DSZ. (2018). INOVACIJE U HRVATSKIM PODUZEĆIMA U RAZDOBLJU 2014. - 2016. Državni zavod za statistiku Republike Hrvatske.

Ekonomski lab, \& Centar za javne politike. (2017). CEA Centar za ekonomske analize i javne politike. Retrieved 12 9, 2019, from Ekonomski lab: https://www.cea-policy.hr/hrvatska-ostaje-74-prema-svjetskoj-konkurentnosti/

Grbac, B., Dlačić, J., \& First, I. (2007.). Trendovi Marketinga. Rijeka: Sveučilište u Rijeci.

Jauk, E., Benedikt, M., Dunst, B., \& Neubauer, C. (2013). The relationship between intelligence and creativity: New support for the threshold hypothesis by means of empirical breakpoint detection. Intelligence, pp. 212-21.

Khessinaa, O., Goncaloa, J., \& Krause, V. $(2018,12)$. It's time to sober up: The direct costs, side effects and long-term consequences of creativity and innovation. Research in Organizational Behavior, pp. 107-135.

Leksikografski zavod Miroslav Krleža. (n.d.). Retrieved 12 6, 2019, from Hrvatska enciklopedija: http://www.enciklopedija.hr/Natuknica.aspx?ID=33832

Miloloža, H. (2016, 11 25). Utjecaj tržišne orijentacije Hrvatskih poduzeća na inovacije proizvoda i usluga. Poslovna izvrsnost, 2(10), pp. 89-105. Retrieved 2019

Ministarstvo gospodarstva, poduzetništva i obrta. (2018). Ministarstvo gospodarstva, poduzetništva i obrta. Retrieved 12. 6., 2019, from Istraživanje i inovacije u gospodarstvu: https://www.mingo.hr/page/kategorija/intelektualno-vlasnistvo-inovacije-nove-tehnologije-odrzivi-razvitak

Porter, M. (1985). Konkurentska prednost. Zagreb: Masmedia.

Prester, J. (2006). Menadžment inovacija. Zagreb: Sinergija.

Sikavica, P., \& Novak, M. (1999). Poslovna organizacija. Zagreb: Informator.

Vrdoljak Raguž, I., \& Tolušić, M. (2012.). Implementacija Porterovih generičkih strategija i postizanje konkurentskih prednosti na primjeru automobilske industrije. Ekonomska misao praksa (1), p. 384. 